\title{
Vizualno in besedilno spletno nasilje v osnovni in srednji šoli: vloga različnih psihosocialnih dejavnikov
}

Igor Peras, Tina Pivec

\section{Uvod}

Medvrstniško nasilje je razširjeno na šolah po svetu in ostaja pereč problem. Z razvojem tehnologije je v zadnjih letih mogoče zaznati porast spletnega medvrstniškega nasilja (v nadaljevanju $S M V N$ ), ki predstavlja premik nasilja iz prostorov šole v virtualno okolje (Lapidot-Lefler in Dolev-Cohen, 2015). Izvajanje SMVN je povezano s porastom uporabe mobilnih telefonov in računalnikov ter se širi preko aplikacij, kot sta Facebook ali Instagram (Dredge et al., 2014). Medvrstniško nasilje predstavljata dve dimenziji, in sicer izvajanje nasilnega vedenja in doživljanje nasilnega vedenja (t. i. viktimizacija). Obe dimenziji sta na kontinuumu, kar pomeni, da se lahko pojavljata tudi hkrati (npr. posameznik ima visoko stopnjo izvajanja in doživljanja nasilnega vedenja). V pričujočem prispevku se sicer osredinjava na dejavnike, ki napovedujejo izvajanje SMVN, medtem ko je viktimizacija vključena kot napovednik.

Izvajanje SMVN se navadno preučuje kot samostojen konstrukt $z$ eno dimenzijo (npr. Skilbred-Fjeld et al., 2020) ali kot ena izmed oblik medvrstniškega nasilja (npr. Pečjak in Pirc, 2017). Nasprotno, Griezel in sodelavci (2012) delijo spletno nasilje na vizualno nasilje (nasilje s slikami in posnet$\mathrm{ki}$ ) in besedilno nasilje (nasilje $\mathrm{z}$ besedilom). Ker so raziskave v Sloveniji vezane predvsem na enodimenzionalno pojmovanje (npr. Brečko, 2019; Javornik et al., 2019; Pečjak in Pirc, 2017), se v pričujočem prispevku osredinjava 
na ločevanje med izvajanjem vizualnega nasilja in izvajanjem besedilnega nasilja $\mathrm{z}$ namenom celovitejšega razumevanja SMVN.

\section{Opredelitev spletnega medvrstniškega nasilja}

SMVN je opredeljeno kot agresivno, namerno dejanje posameznika ali skupine, ki z uporabo elektronskih oblik komunikacije ponavljajoče in skozi čas nadleguje žrtev, ki se ne more zlahka braniti (Smith et al., 2008). Definicija je izpeljana iz izvorne opredelitve medvrstniškega nasilja (Olweus, 1994) in vključuje tri kriterije za presojanje o nasilju: (i) dejanja so povzročena namerno, (ii) dejanja se ponavljajo in (iii) med spletno žrtvijo ter spletnim nasilnežem je prisotna neenakost $\mathrm{v}$ porazdelitvi moči. V izrednih situacijah že enkratno nasilno dejanje opredeljujemo kot SMVN, npr. ko slika ali komentar ostane na spletu dlje časa ali je vidna večjemu številu ljudi (Gámez-Guadix et al., 2013; Langos, 2012), SMVN pa se tudi razlikuje od ostalih oblik medvrstniškega nasilja (telesnega, besednega, odnosnega) (Kowalski et al., 2014; Patchin in Hinduja, 2011): spletni nasilnež za izvajanje nasilja ni nujno v neposredni bližini spletne žrtve, nasilje se lahko izvaja anonimno, dogaja se kadarkoli v dnevu, nasilje se lahko širi veliko hitreje, doseže potencialno večje število opazovalcev in traja daljše časovno obdobje.

SMVN se širi preko različnih orodij spletnega komuniciranja (npr. neposredna sporočila, socialna omrežja) (Kowalski et al., 2014). Zaradi značilnosti teh orodij izvajanje nasilja delimo na: vizualno nasilje (izvajanje nasilja s pošiljanjem, objavljanjem ali ustvarjanjem videoposnetkov in slik, npr. snemanje in fotografiranje učenca $z$ namenom osramotitve) in besedilno nasilje (izvajanje nasilja s pošiljanjem in objavljanjem besedil, npr. pošiljanje sporočil z grožnjami) (za podrobnejši pregled primerov glej Griezel et al., 2012; Košir, 2013).

Ocene prevalence SMVN se v tujih raziskavah gibljejo med $4 \%$ do 70 \% (Aboujaoude et al., 2015; Brochado et al., 2017; Kowalski et al., 2014) in so odvisne od raziskovalnega načrta (npr. če se v raziskavi preučuje vključenost v SMVN v zadnjem mesecu, šolskem letu ali za obdobje celotnega šolanja). Ugotovitve slovenske raziskave (Pečjak in Pirc, 2017) kažejo, da je 3,9 \% učencev višjih razredov osnovnih šol in dijakov srednjih šol poročalo, da so v zadnjih 30 dneh izvajali SMVN; 4,1 \% učencev in dijakov pa se je v enakem obdobju znašlo v obeh vlogah (spletni nasilnež-žrtev).

Udeleženost v SMVN se povezuje s psihološkimi stiskami (Patchin in Hinduja, 2006; Kaiser et al., 2020; Skilbred-Fjeld et al., 2020). Posledice so 
prisotne tako pri spletnih nasilnežih kot tudi pri spletnih žrtvah. Campbell in sodelavci (2013) ugotavljajo, da spletni nasilneži poročajo o težavah na področju duševnega zdravja in navezovanja socialnih stikov $\mathrm{z}$ drugimi učenci. Prav tako pa spletni nasilneži poročajo o višjih ravneh depresije, anksioznosti in stresa (Campbell et al., 2013) in nižjih ravneh samospoštovanja (Patchin in Hinduja, 2010). Žrtve SMVN poročajo o občutkih anksioznosti, depresivnosti, obupa, jeze, frustracije, nemoči, strahu, ranljivosti, osamljenosti in težavah z vrstniškimi odnosi (Cassidy et al., 2013; Patchin in Hinduja, 2006).

\section{Individualne značilnosti učencev kot dejavniki spletnega medvrstniškkega nasilja}

Dejavniki, ki prispevajo k SMVN so izpeljani na podlagi preteklih ugotovitev, ki jih navajava spodaj in vključujejo spol, šolski uspeh, čas aktivne uporabe socialnih omrežij, komponente izražanja jeze (eksternalizacija jeze, internalizacija jeze, nadzor jeze), doživljanje vrstniških odnosov (samozaznana priljubljenost, zaznana opora s strani vrstnikov), viktimizacijo (vizualna viktimizacija, besedilna viktimizacija) in izvajanje nasilja (vizualno nasilje, besedilno nasilje).

Spol je zelo preučevan dejavnik, vendar dosedanje raziskave ne dajejo enoznačnih odgovorov. Več raziskav poroča, da je izvajanje SMVN bolj značilno za fante $\mathrm{v}$ primerjavi $\mathrm{z}$ dekleti (Aboujaoude et al., 2015; Baldry et al., 2015; Erdur-Baker, 2010; Guo, 2016; Lapidot-Lefler in Dolev-Cohen, 2015; $\mathrm{Li}, 2006$ ). $\mathrm{V}$ nasprotju $\mathrm{z}$ omenjenim nekatere raziskave (Sourander et al., 2010; Antoniadou et al., 2016; Del Rey et al., 2016; Smith et al., 2008) poročajo, da med spoloma ni razlik v izvajanju SMVN oziroma da se dekleta znajdejo večkrat $\mathrm{v}$ vlogi izvajalk spletnega nasilja $\mathrm{v}$ primerjavi s fanti (Kowalski in Limber, 2007).

Šolski uspeh je negativno povezan z izvajanjem SMVN (Kowalski et al., 2014; Kowalski in Limber, 2013). Torej, učenci, ki poročajo o pogostejšem izvajanju SMVN, poročajo o nižjem šolskem uspehu. Prav tako v sistematičnem pregledu (Baldry et al., 2015) in vzdolžni raziskavi (Hemphill et al., 2012) avtorji ugotavljajo, da sta za spletne nasilneže značilna nižji šolski uspeh in nižja zavzetost pri opravljanju šolskih obveznosti.

Kot pomemben dejavnik izvajanja SMVN se je izkazal tudi čas, ki ga učenci preživijo na spletu ali socialnih omrežjih. Čas uporabe spleta je pozitivno povezan z izvajanjem SMVN (Kowalski et al., 2014; Guo, 2016; 
Kowalski et al., 2019), kar pomeni, da večja uporaba spleta in socialnih omrežij pomeni pogostejše izvajanje SMVN.

Občutki jeze se pozitivno povezujejo z izvajanjem SMVN (Kowalski et al., 2014; Wang et al., 2017). Aricak in Ozbay (2016) navajata, da dve od treh komponent izražanja jeze: jeza usmerjena navzven (eksternalizacija jeze) in jeza usmerjena navznoter (internalizacija jeze) pozitivno napovedujeta izvajanje SMVN. Torej, učenci z višjimi ravnimi jeze oziroma posameznimi komponentami jeze, poročajo o pogostejšem izvajanju SMVN.

Dejavniki, ki prispevajo k SMVN so vezani tudi na doživljanje vrstniških odnosov. Med pokazatelja doživljanja vrstniških odnosov učencev uvrščamo samozaznano priljubljenost in zaznano oporo s strani vrstnikov. Samozaznana priljubljenost je opredeljena kot položaj učenca v vrstniški skupini in se nanaša na vidnost ter dominantnost (de Bruyn et al., 2010). Dosedanje raziskave ne dajejo enoznačnih odgovorov o povezavi med izvajanjem SMVN in samozaznano priljubljenostjo. Wright (2014) ugotavlja, da SMVN izvajajo tako učenci, ki se zaznavajo kot bolj priljubljene, kot tudi učenci, ki se zaznavajo kot manj priljubljene, kar nakazuje, da učenci SMVN izvajajo iz različnih razlogov. Bayraktar in Wright (2021) poročata, da samozaznana nepriljubljenost (obratno vrednotena samozaznana priljubljenost) negativno napoveduje izvajanje SMVN, kar pomeni, da učenci, ki se zaznavajo kot bolj priljubljene, pogosteje izvajajo SMVN. Zaznana opora s strani vrstnikov je prav tako preučevan konstrukt, ki se povezuje z izvajanjem SMVN. Dosedanje ugotovitve (Calvete et al., 2010; Williams in Guerra, 2007) kažejo, da učenci, ki poročajo o nižjih ravneh zaznane opore, poročajo o pogostejšem izvajanju SMVN.

Udeleženost $\mathrm{v}$ procesu $\mathrm{t}$. i. tradicionalnega medvrstniškega nasilja (npr. telesno, besedno in odnosno nasilje) kot nasilnež ali žrtev je pozitiven napovednik izvajanja SMVN (Kowalski et al., 2014; Guo, 2016). Kowalski in sodelavci (2014) z metaanalizo ugotavljajo, da je spletna viktimizacija eden izmed najmočnejših napovednikov izvajanja SMVN in da je izvajanje SMVN najmočnejši napovednik spletne viktimizacije, kar nakazuje na recipročen odnos med doživljanjem nasilja in izvajanjem nasilja. Omenjena metaanaliza ugotavlja tudi podobno povezavo med izvajanjem tradicionalnega medvrstniškega nasilja in izvajanjem SMVN. Torej, učenci, ki so tradicionalni nasilneži (telesni, besedni, odnosni), so tudi spletni nasilneži, kar pomeni, da ena oblika nasilnega vedenja napoveduje drugo obliko nasilnega vedenja. 
Dejavnike bova preučila ločeno glede na stopnjo izobraževanja, in sicer posebej za učence osnovne šole in za dijake srednje šole, saj nekatere raziskave (Smith et al., 2008; Del Rey et al., 2016) poročajo, da se spletno nasilje v večji meri pojavlja pri starejših učencih v primerjavi z mlajšimi.

\section{Pričujoča študija}

Dejavniki, ki prispevajo k SMVN so v mednarodnem raziskovalnem prostoru dobro raziskani (Kowalski et al., 2019; Kowalski et al., 2014; Sticca et al., 2013; Chen et al., 2017; Zych et al., 2019). Delna raziskovalna vrzel se pojavlja $\mathrm{v}$ slovenskem raziskovalnem prostoru, kjer je SMVN sicer predmet preučevanja (npr. Brečko, 2019; Javornik et al., 2019; Pečjak in Pirc, 2017), vendar je bilo več poudarka na preučevanju tradicionalnega medvrstniškega nasilja (Šulc in Bučar Ručman, 2019) oziroma njegovih dejavnikih (Košir et al., 2020; 2018). S pričujočo raziskavo skušava bolje razumeti dejavnike izvajanja vizualnega in besedilnega nasilja ločeno glede na vzorec osnovnošolcev in srednješolcev. Na podlagi teoretičnih izhodišč sva oblikovala naslednji raziskovalni vprašanji:

- Kateri dejavniki in kako napovedujejo izvajanje vizualnega spletnega medvrstniškega nasilja v osnovni šoli in srednji šoli?

- Kateri dejavniki in kako napovedujejo izvajanje besedilnega spletnega medvrstniškega nasilja v osnovni šoli in srednji šoli?

\section{Metoda}

\section{Udeleženci}

$\mathrm{V}$ prispevku uporabljava podatke širše raziskave spletnega medvrstniškega nasilja (SMVN) izvedene na Oddelku za psihologijo Filozofske fakultete Univerze v Mariboru pod vodstvom izr. prof. dr. Katje Košir. Vzorec vključuje 1921 učencev (59,9 \% deklet; $M=15,52$ let; $S D=1,49$ let) višjih razredov osnovne šole in dijakov srednje šole (v nadaljevanju uporabljava enoten izraz učenci), ki so bili stari med 13 in 19 let. Osnovnošolski vzorec vključuje 695 učencev (50,9 \% deklet; $M=13,95$ let; $S D=0,69$ let), srednješolski vzorec vključuje 1226 učencev (64,9\% deklet; $M=16,42$ let; $S D=1$, oo let) iz 12 osnovnih šol in 8 srednjih šol (3 gimnazije, 4 poklicne šole in 1 poklicna šola $\mathrm{z}$ gimnazijskim programom) iz 2 statističnih regij v Sloveniji. 


\section{Pripomočki}

Spletno nasilje in viktimizacija. Revidiran vprašalnik medvrstniških odnosov: spletno nasilno vedenje/spletna viktimizacija (Revised Adolescent Peer Relations Instrument-Bully/Target; Griezel et al., 2012) je bil uporabljen kot mera izvajanja in doživljanja SMVN. Sestavljen je iz 26 postavk na 6-stopenjski Likertovi lestvici $(» 1=$ nikoli $«, ~ " 2=$ redko«, "3 = enkrat ali dvakrat na mesec «, $\gg 4=$ enkrat na teden $«, ~ " 5=$ nekajkrat na teden $«, ~ » 6=$ vsak dan«), ki se nanašajo na SMVN v preteklem šolskem letu. Psihometrične značilnosti so bile preverjene na tujem vzorcu (Griezel et al., 2012). $\mathrm{V}$ prispevku so uporabljene dimenzije: vizualno nasilje, ki vključuje 5 postavk (»Posredoval/a videoposnetek učenca/ke, $\mathrm{z}$ namenom, da ga/jo osramotim«; Cronbach a koeficienta 0,83 in 0,78 za OŠ in SŠ vzorec), besedilno nasilje, ki vključuje 8 postavk (»Učencu/ki poslal/a besedilno sporočilo, za katero sem vedel/a, da ga/jo bo prizadelo«; Cronbach a koeficienta 0,78 in o,72 za OŠ in SŠ), vizualna viktimizacija (»Je nekdo brez mojega dovoljenja uporabil moj račun za pošiljanje video sporočila drugim. S tem me je želel spraviti v težave«; Cronbach a koeficienta 0,68 in o,73 za OŠ in SŠ) in besedilna viktimizacija (»Mi je učenec/ka poslal sporočilo preko socialnega omrežja in mi v njem grozil/a, da mi bo škodil/a«; Cronbach a koeficienta 0,82 in 0,83 za OŠ in $S \check{S}$ ).

Izražanje jeze. Indeks izražanja jeze (Anger Expression Index-Adolescent; Parada, 2006) je bil uporabljen kot mera izražanja jeze. Sestavljen je iz 12 postavk na 6 -stopenjski lestvici ( $» 1=$ nikoli« - $» 6=$ vedno ), ki merijo tri dimenzije: internalizacijo jeze (»Je v meni veliko besa, čeprav se to ne vidi navzven«), eksternalizacijo jeze (»Se prepiram z drugimi «) in nadzor jeze (»Nadzorujem svoja jezna občutja«). Mera je zanesljiva na slovenskem vzorcu (Košir et al., 2020). Vrednosti Cronbachovega $\alpha$ koeficienta so za internalizacijo jeze, eksternalizacijo jeze in nadzor jeze znašale $0,74,0,66$ in 0,84 na OŠ ter $0,73,0,67$ in 0,86 na SŠ vzorcu.

Zaznana opora s strani vrstnikov. Lestvica zaznane opore (Classroom Life Instrument, Johnson et al., 1983) je bila uporabljena kot mera zaznane opore. V prispevek je vključena zgolj dimenzija socialna opora s strani vrstnikov, sestavljena iz 5 postavk (»Moji sošolci me zares marajo «) na 5-stopenjski lestvici ( $(1=$ nikoli ne drži $\lll$ - $" 5=$ vedno drži $\lll)$. Slovenska priredba ima zadovoljive psihometrične lastnosti (Košir in Pečjak, 2007). Vrednost Cronbachovega $\alpha$ koeficienta je $v$ naši študiji znašala 0,87 na OŠ in 0,86 na SŠ vzorcu.

Samozaznana priljubljenost. Merjena $\mathrm{z}$ eno postavko: »Oceni, kako si v primerjavi $\mathrm{z}$ drugimi $\mathrm{v}$ razredu/letniku po tvojem mnenju priljubljen med 
sošolci?« na 5-stopenjski Likertovi lestvici (»1 = mnogo manj kot večina« - "5 = mnogo več kot večina«). Uporaba ene postavke za merjenje samozaznane priljubljenosti je sprejemljiva (Cillessen in Marks, 2011).

Šolski uspeh. Učenci so poročali o zaključnih ocenah v preteklem šolskem letu pri slovenščini, matematiki in prvem tujem jeziku. Navajali so ocene od 1 (nezadostno) do 5 (odlično). Na podlagi tega je izračunano povprečje.

Čas aktivne uporabe socialnih omrežji. Učenci so ocenili, koliko časa na dan aktivno uporabljajo socialna omrežja. Aktivna uporaba je bila definirana kot čas, ko imajo aplikacijo odprto in jo uporabljajo. Čas aktivne uporabe socialnih omrežij je izražen v minutah.

\section{Postopek}

Izvedbo raziskave je potrdila Komisija za etičnost raziskovanja FF UM. Šole so bile povabljene priložnostno preko e-pošte. Izvedba raziskave je potekala na podlagi strinjanja šole, soglasja staršev oz. soglasja dijakov (za starejše od 18 let). Zbiranje podatkov je potekalo maja in junija 2019 po metodi papir-svinčnik v razredih. Uporabljena je bila baterija vprašalnikov, ki je poleg izbranih mer v tem prispevku vključevala še nekatere druge koncepte (npr. osamljenost, motivi za izvajanje nasilja). Pred reševanjem sta bili učencem podani ustni definiciji spletnega in tradicionalnega medvrstniškega nasilja. Anonimno reševanje je trajalo med 30 in 45 minut.

\section{Analize}

Podatke sva statistično obdelala v IBM SPSS 27. Izračunala sva opisne statistike, korelacije med spremenljivkami in hierarhične regresijske analize $\mathrm{z}$ metodo vključitve (angl. enter). Kot odvisni spremenljivki sta bili vključeni vizualno nasilje in besedilno nasilje. Regresije so bile izvedene ločeno za OŠ in SŠ vzorec. Preliminarne analize so pokazale izpolnitev predpostavk za izvedbo hierarhične regresijske analize. Indikatorji VIF (angl. variance inflation factor) kažejo, da v podatkih ni težav $\mathrm{z}$ multikolinearnostjo (VIF med 1 in 4). Pri preverjanju obstoja vplivnih točk, ki lahko popačijo regresijski model, odstopanj ni mogoče zaznati (vrednosti Cookove razdalje med o,oo in o,24). Za izbrane modele prav tako bistveno ne kršiva predpostavk homoskedastičnosti, linearnosti in približne normalne porazdelitve rezidualov. Spremenljivke so v regresijske analize vključene v petih korakih. V prvem koraku so vključene demografske spremenljivke (spol, šolski uspeh, čas aktivne uporabe socialnih omrežij), v drugem koraku komponente izražanja jeze (eksternalizacija jeze, internalizacija jeze, nadzor jeze), v 
tretjem koraku spremenljivki doživljanja vrstniških odnosov (samozaznana priljubljenost, zaznana opora s strani vrstnikov), v četrtem koraku doživljanje nasilnega vedenja (vizualna viktimizacija, besedilna viktimizacija) in v petem koraku izvajanje nasilnega vedenja (vizualno nasilje, besedilno nasilje). Torej, najprej so v modele vključene spremenljivke, ki se nanašajo na individualne značilnosti učencev in vrstniške odnose, nazadnje so vključene spremenljivke viktimizacije ter nasilja, ki navadno pojasnjujejo največ variance izvajanja nasilja (glej npr. Kowalski et al., 2014).

\section{Rezultati}

V nadaljevanju najprej predstavljava opisne statistike in Pearsonove korelacijske koeficiente, nato sledijo rezultati hierarhičnih regresijskih analiz. Rezultati so predstavljeni ločeno glede na osnovnošolski (OŠ) in srednješolski vzorec (SŠ).

Vizualno in besedilno nasilje: osnovnošolski vzorec

Tabela i6: Opisne statistike in korelacije na vzorcu učencev OŠ

\begin{tabular}{|c|c|c|c|c|c|c|c|c|c|c|c|c|c|c|}
\hline & & M & SD & 1 & 2 & 3 & 4 & 5 & 6 & 7 & 8 & 9 & 10 & 11 \\
\hline 1 & $\mathrm{Spol}^{\mathrm{a}}$ & 0,51 & I & & & & & & & & & & & \\
\hline 2 & $\begin{array}{l}\text { Šolski } \\
\text { uspeh }\end{array}$ & 3,72 & 0,89 & $0,13^{* *}$ & & & & & & & & & & \\
\hline 3 & $\begin{array}{l}\text { Čas } \\
\text { uporabe }\end{array}$ & 171,27 & 128,02 & $0,13^{* *}$ & $-0,25^{* *}$ & & & & & & & & & \\
\hline 4 & INT jeze & 3,39 & 1,14 & $0,23^{* *}$ & $0,20^{* 1}$ & 0,14 & & & & & & & & \\
\hline 5 & EKS jeze & 2,83 & 1,02 & $-0,01$ & 0,04 & $0,21^{*}$ & $0,36^{* \prime}$ & & & & & & & \\
\hline 6 & $\begin{array}{l}\text { Nadzor } \\
\text { jeze }\end{array}$ & 3,73 & 1,22 & $-0,08^{*}$ & 0,04 & $-0,20^{* *}$ & $-0,19$ & $-0,40^{* *}$ & & & & & & \\
\hline 7 & Opora & 3,44 & 0,83 & $-0,09^{\circ}$ & 0,05 & 0,02 & $-0,16^{*}$ & 0,01 & $0,12^{* *}$ & & & & & \\
\hline 8 & $\begin{array}{l}\text { Priljublje- } \\
\text { nost }\end{array}$ & 3,07 & 0,84 & $-0,13$ & $-0,01$ & $0,12^{* *}$ & $-0,09^{\circ}$ & $0,17^{* *}$ & $-0,09^{*}$ & $0,44^{*}$ & & & & \\
\hline 9 & $\begin{array}{l}\text { VIZ } \\
\text { nasilje }\end{array}$ & 1,46 & 0,66 & 0,01 & $-0,07$ & $0,30^{* *}$ & 0,07 & $0,25^{* *}$ & $-0,22^{*}$ & 0,05 & $0,24^{* *}$ & & & \\
\hline 10 & $\begin{array}{l}\text { BES } \\
\text { nasilje }\end{array}$ & 1,34 & 0,43 & $-0,02$ & $-0,09^{*}$ & $0,32^{\prime \prime}$ & $0,14^{*}$ & $0,33^{* \prime}$ & $-0,21^{* \prime}$ & 0,03 & $0,20^{* *}$ & $0,61 *$ & & \\
\hline 11 & $\begin{array}{l}\text { Vizualna } \\
\text { VIK }\end{array}$ & 1,29 & 0,43 & 0,01 & $-0,05$ & $0,19^{* *}$ & $0,13^{* *}$ & $0,19^{* *}$ & $-0,13$ & $-0,08^{\circ}$ & $0,10^{\circ}$ & $0,49^{* *}$ & $0,49^{*}$ & \\
\hline 12 & $\begin{array}{l}\text { Besedilna } \\
\text { VIK }\end{array}$ & 1,32 & 0,44 & 0,07 & 0,02 & $0,19^{\prime *}$ & $0,19^{* *}$ & $0,17^{* *}$ & $-0,12$ & $-0,17^{* *}$ & 0,04 & $0,39^{* *}$ & $0,47^{* *}$ & $0,80^{* *}$ \\
\hline
\end{tabular}

Opombe. Spola: $\mathrm{O}=$ moški, I = ženski; ${ }^{*} \mathrm{p}<0,05 ;{ }^{* *} \mathrm{p}<0,0$ r; čas uporabe - čas aktivne uporabe socialnih omrežij; INT jeze - internalizacija jeze; EKS jeze - eksternalizacija jeze; opora - zaznana opora s strani vrstnikov; priljubljenost - samozaznana priljubljenost; VIZ nasilje - vizualno nasilje; BES nasilje - besedilno nasilje; vizualna VIK - vizualna viktimizacija; besedilna VIK - besedilna viktimizacija. 
Iz Tabele 16 je razvidno, da z vizualnim nasiljem korelirajo čas aktivne uporabe socialnih omrežij, eksternalizacija jeze, nadzor jeze, samozaznana priljubljenost, besedilno nasilje, vizualna viktimizacija in besedilna viktimizacija. Z besedilnim nasiljem korelirajo šolski uspeh, čas aktivne uporabe socialnih omrežij, internalizacija jeze, eksternalizacija jeze, nadzor jeze, samozaznana priljubljenost, vizualno nasilje, besedilna viktimizacija in vizualna viktimizacija. Spremenljivke se povezujejo v pričakovani smeri. Korelacije so večinoma nizke $(r<0,30)$, razen v primeru korelacij med spremenljivkami SMVN (npr. vizualnim nasiljem in vizualno viktimizacijo).

Tabela 17: Hierarhična regresijska analiza za spremenljivke, ki napovedujejo izvajanje vizualnega nasilja v osnovni šoli

\begin{tabular}{|c|c|c|c|c|c|c|c|c|c|c|}
\hline \multicolumn{11}{|c|}{ Vizualno nasilje OŠ } \\
\hline & \multicolumn{2}{|c|}{ Model 1} & \multicolumn{2}{|c|}{ Model 2} & \multicolumn{2}{|c|}{ Model 3} & \multicolumn{2}{|c|}{ Model 4} & \multicolumn{2}{|c|}{ Model 5} \\
\hline & B & $\beta$ & B & $\beta$ & $\mathrm{B}$ & $\beta$ & B & $\beta$ & $\mathrm{B}$ & $\beta$ \\
\hline \multicolumn{11}{|c|}{ Korak 1: } \\
\hline Spol $^{\mathrm{a}}$ & $-0,04$ & $-0,03$ & $-0,03$ & $-0,02$ & 0,00 & 0,00 & 0,01 & 0,01 & 0,04 & 0,03 \\
\hline Šolski uspeh & 0,01 & 0,01 & 0,00 & 0,01 & 0,00 & 0,00 & 0,01 & 0,01 & 0,02 & 0,03 \\
\hline Čas uporabe & 0,00 & $0,30^{* *}$ & 0,00 & $0,25^{* *}$ & 0,00 & $0,23^{* *}$ & 0,00 & $0,17^{* *}$ & 0,00 & $0,09^{* *}$ \\
\hline $\mathrm{R}^{2}$ & & $0,09^{* *}$ & & & & & & & & \\
\hline \multicolumn{11}{|c|}{ Korak 2: } \\
\hline INT jeze & & & $-0,03$ & $-0,05$ & $-0,01$ & $-0,02$ & $-0,03$ & $-0,05$ & $-0,03$ & $-0,05$ \\
\hline EKS jeze & & & 0,11 & $0,16^{* *}$ & 0,09 & $0,13^{* *}$ & 0,06 & $0,08^{*}$ & 0,00 & 0,00 \\
\hline Nadzor jeze & & & $-0,06$ & $-0,12^{* *}$ & $-0,06$ & $-0,10^{*}$ & $-0,04$ & $-0,10^{*}$ & $-0,04$ & $-0,07^{*}$ \\
\hline$\Delta \mathrm{R}^{2}$ & & & & $0,05^{* *}$ & & & & & & \\
\hline \multicolumn{11}{|c|}{ Korak 3: } \\
\hline Opora & & & & & $-0,02$ & $-0,03$ & $-0,02$ & $-0,02$ & 0,00 & 0,00 \\
\hline Priljubljenost & & & & & 0,15 & $0,19^{* *}$ & 0,11 & $0,14^{* *}$ & 0,08 & $0,10^{* *}$ \\
\hline$\Delta \mathrm{R}^{2}$ & & & & & & $0,03^{* *}$ & & & & \\
\hline \multicolumn{11}{|c|}{ Korak 4: } \\
\hline $\begin{array}{l}\text { Vizualna } \\
\text { viktimizacija }\end{array}$ & & & & & & & 0,68 & $0,43^{* *}$ & 0,51 & $0,33^{* *}$ \\
\hline $\begin{array}{l}\text { Besedilna } \\
\text { viktimizacija }\end{array}$ & & & & & & & $-0,01$ & $-0,01$ & $-0,16$ & $-0,11^{*_{1}}$ \\
\hline$\Delta \mathrm{R}^{2}$ & & & & & & & & $0,17^{* *}$ & & \\
\hline
\end{tabular}




\begin{tabular}{|c|c|c|c|c|c|c|c|c|c|c|}
\hline \multicolumn{11}{|c|}{ Vizualno nasilje OŠ } \\
\hline & \multicolumn{2}{|c|}{ Model 1} & \multicolumn{2}{|c|}{ Model 2} & \multicolumn{2}{|c|}{ Model 3} & \multicolumn{2}{|c|}{ Model 4} & \multicolumn{2}{|c|}{ Model 5} \\
\hline & B & $\beta$ & B & $\beta$ & B & $\beta$ & B & $\beta$ & B & $\beta$ \\
\hline \multicolumn{11}{|c|}{ Korak 5: } \\
\hline $\begin{array}{l}\text { Besedilno } \\
\text { nasilje }\end{array}$ & & & & & & & & & 0,69 & $0,45^{* *}$ \\
\hline$\Delta \mathrm{R}^{2}$ & & & & & & & & & & $0,13^{* *}$ \\
\hline $\mathrm{R}^{2}$ & & $0,09^{* *}$ & & $0,14^{* *}$ & & $0,16^{* *}$ & & $0,33^{* *}$ & & $0,46^{* *}$ \\
\hline $\mathrm{F} z a \Delta \mathrm{R}^{2}$ & & $22,18^{* *}$ & & $12,59^{* *}$ & & $11,59^{* *}$ & & $85,74^{* *}$ & & $158,52^{* *}$ \\
\hline
\end{tabular}

Opombe. Spola: o = moški, I = ženski; ${ }^{*} \mathrm{P}<0,05 ;{ }^{* *} \mathrm{p}<0,0 \mathrm{I}$ : I $\mathrm{P}<0, \mathrm{IO}$; I - supresorski učinek v modelu, čas uporabe - čas aktivne uporabe socialnih omrežij; INT jeze - internalizacija jeze; EKS jeze - eksternalizacija jeze; opora - zaznana opora s strani vrstnikov; priljubljenost - samozaznana priljubljenost.

Iz Tabele 17 je razvidno, da demografske spremenljivke, ki so vključene v prvem koraku, pojasnijo $9 \%$ variance vizualnega nasilja. Čas aktivne uporabe socialnih omrežij je značilen pozitiven napovednik. Vključitev komponent jeze v drugem koraku dodatno pojasni $5 \%$ variance, pri čemer je eksternalizacija jeze značilen pozitiven napovednik, nadzor jeze pa značilen negativen napovednik. V tretjem koraku vključene spremenljivke doživljanja vrstniških odnosov pojasnijo dodatnih $3 \%$ variance, pri čemer je samozaznana priljubljenost značilen pozitiven napovednik. $\mathrm{V}$ četrtem koraku vneseni spremenljivki viktimizacije dodatno pojasnita $17 \%$ variance vizualnega nasilja, pri čemer je vizualna viktimizacija značilen pozitiven napovednik, besedilna viktimizacija pa ni značilen napovednik. V petem koraku besedilno nasilje kot značilen pozitiven napovednik dodatno pojasni 13 \% variance. Eksternalizacija jeze v petem koraku izgubi statistično značilnost. Besedilna viktimizacija postane značilen negativen napovednik, kar glede na pozitivno korelacijo med vizualnim nasiljem in besedilno viktimizacijo pomeni, da je v modelu nastal supresorski učinek (angl. supressor effect) (Smith et al., 1992). Skupaj napovedniki pojasnijo $46 \%$ variance odvisne spremenljivke vizualno nasilje, pri čemer največja sprememba $\mathrm{v}$ deležu pojasnjene variance nastane $\mathrm{v}$ četrtem koraku. Najmočnejši napovednik pa je besedilno nasilje $\mathrm{v}$ petem koraku. Valence napovednikov kažejo, da so učenci z višjim časom aktivne uporabe socialnih omrežij, manjšim nadzorom jeze, višjo samozaznano priljubljenostjo, višjo vizualno viktimizacijo in višjim besedilnim nasiljem tisti, ki v višji meri poročajo o izvajanju vizualnega nasilja. 
Tabela ı: Hierarhična regresijska analiza za spremenljivke, ki napovedujejo izvajanje besedilnega nasilja v osnovni šoli

\begin{tabular}{|c|c|c|c|c|c|c|c|c|c|c|}
\hline \multicolumn{11}{|c|}{ Besedilno nasilje OŠ } \\
\hline & \multicolumn{2}{|c|}{ Model 1} & \multicolumn{2}{|c|}{ Model 2} & \multicolumn{2}{|c|}{ Model 3} & \multicolumn{2}{|c|}{ Model 4} & \multicolumn{2}{|c|}{ Model 5} \\
\hline & B & $\beta$ & B & $\beta$ & B & $\beta$ & B & $\beta$ & B & $\beta$ \\
\hline \multicolumn{11}{|c|}{ Korak 1: } \\
\hline $\mathrm{Spol}^{\mathrm{a}}$ & $-0,06$ & $-0,07$ & $-0,05$ & $-0,06$ & $-0,04$ & $-0,05$ & $-0,04$ & $-0,05$ & $-0,04$ & $-0,05^{1}$ \\
\hline Šolski uspeh & 0,00 & 0,00 & $-0,02$ & $-0,03$ & $-0,02$ & $-0,04$ & $-0,02$ & $-0,04$ & $-0,02$ & $-0,05$ \\
\hline Čas uporabe & 0,00 & $0,33^{* *}$ & 0,00 & $0,25^{* *}$ & 0,00 & $0,24^{* *}$ & 0,00 & $0,17^{* *}$ & 0,00 & $0,10^{* *}$ \\
\hline $\mathrm{R}^{2}$ & & $0,11^{* *}$ & & & & & & & & \\
\hline \multicolumn{11}{|l|}{ Korak 2: } \\
\hline INT jeze & & & 0,01 & 0,02 & 0,02 & 0,04 & 0,00 & 0,01 & 0,01 & 0,02 \\
\hline EKS jeze & & & 0,11 & $0,25^{* *}$ & 0,10 & $0,23^{* *}$ & 0,08 & $0,18^{* *}$ & 0,06 & $0,15^{* *}$ \\
\hline Nadzor jeze & & & $-0,02$ & $-0,06$ & $-0,02$ & $-0,06$ & $-0,02$ & $-0,01$ & 0,00 & $-0,01$ \\
\hline
\end{tabular}

\begin{tabular}{lrllllll}
\multicolumn{1}{c}{ Korak 3: } & & & & & \\
\hline Opora & $-0,02$ & $-0,03$ & 0,03 & 0,05 & 0,02 & 0,04 \\
\hline Priljubljenost & 0,07 & $0,14^{* *}$ & 0,04 & $0,09 *$ & 0,02 & 0,03 \\
\hline$\Delta \mathrm{R}^{2}$ & & $0,02^{* *}$ & & & &
\end{tabular}

\begin{tabular}{|c|c|c|c|c|c|c|c|}
\hline \multicolumn{8}{|c|}{ Korak 4: } \\
\hline Vizualna VIK & & & & 0,24 & $0,24^{* *}$ & 0,05 & 0,05 \\
\hline $\begin{array}{l}\text { Besedilna } \\
\text { VIK }\end{array}$ & & & & 0,22 & $0,22^{* *}$ & 0,22 & $0,23^{* *}$ \\
\hline$\Delta \mathrm{R}^{2}$ & & & & & $0,17^{* *}$ & & \\
\hline \multicolumn{8}{|c|}{ Korak 5: } \\
\hline $\begin{array}{l}\text { Vizualno } \\
\text { nasilje }\end{array}$ & & & & & & 0,27 & $0,42^{* *}$ \\
\hline$\Delta \mathrm{R}^{2}$ & & & & & & & $0,12^{* *}$ \\
\hline $\mathrm{R}^{2}$ & $0,11^{* *}$ & $0,19^{* *}$ & $0,20^{* *}$ & & $0,37^{* *}$ & & $0,49^{* *}$ \\
\hline $\mathrm{F}$ za $\Delta \mathrm{R}^{2}$ & $27,55^{* *}$ & $22,21^{* *}$ & $6,53^{* *}$ & & $92,16^{* *}$ & & $158,52^{* *}$ \\
\hline
\end{tabular}

Opombe. Spola: o = moški, I = ženski; ${ }^{*} \mathrm{p}<0,05 ;{ }^{* *} \mathrm{p}<0,0$ I: $\mathrm{Ip}<0$, IO; čas uporabe čas aktivne uporabe socialnih omrežij; INT jeze - internalizacija jeze; EKS jeze eksternalizacija jeze; opora - zaznana opora s strani vrstnikov; priljubljenost - samozaznana priljubljenost; vizualna VIK - vizualna viktimizacija, besedilna VIK - besedilna viktimizacija. 
Iz Tabele 18 je razvidno, da demografske spremenljivke vključene v prvem koraku, pojasnijo $11 \%$ variance besedilnega nasilja. Pri čemer je spremenljivka čas aktivne uporabe socialnih omrežij značilen pozitiven napovednik. Komponente jeze vnesene v drugem koraku dodatno pojasnijo $8 \%$ variance, pri čemer je eksternalizacija jeze značilen pozitiven napovednik. $\mathrm{V}$ tretjem koraku vnesene spremenljivke doživljanja vrstniških odnosov dodatno pojasnijo $2 \%$ variance. Spremenljivka samozaznana priljubljenost je značilen pozitiven napovednik. V četrtem koraku vneseni spremenljivki viktimizacije dodatno pojasnita $17 \%$ variance, pri čemer sta vizualna viktimizacija in besedilna viktimizacija statistično značilna pozitivna napovednika. $\mathrm{V}$ petem koraku vnesena spremenljivka vizualno nasilje dodatno pojasni $12 \%$ variance in je značilen pozitiven napovednik, medtem ko samozaznana priljubljenost in vizualna viktimizacija nista več značilna. Skupaj napovedniki pojasnijo 49 \% variance besedilnega nasilja, pri čemer $\mathrm{k}$ največji spremembi variance prispeva četrti model. Najmočnejši napovednik je vizualno nasilje. Valence napovednikov kažejo, da so učenci z višjim časom aktivne uporabe socialnih omrežij, višjo eksternalizacijo jeze, višjo besedilno viktimizacijo in višjim vizualnim nasiljem tisti, ki v višji meri poročajo o izvajanju besedilnega nasilja. Prav tako spremenljivka spol, ki se ni izkazala kot statistično značilen napovednik, dosega pa mejno vrednost pri $\alpha<0,10$, nakazuje, da so fantje v primerjavi $z$ dekleti tisti, ki poročajo o višjih ravneh izvajanja besedilnega nasilja.

\section{Vizualno in besedilno nasilje: srednješolski vzorec}

Iz Tabele 19 je razvidno, da z vizualnim nasiljem korelirajo spol, čas aktivne uporabe socialnih omrežij, internalizacija jeze, eksternalizacija jeze, nadzor jeze, samozaznana priljubljenost, besedilno nasilje, vizualna viktimizacija in besedilna viktimizacija. Z besedilnim nasiljem korelirajo spol, šolski uspeh, čas aktivne uporabe socialnih omrežij, internalizacija jeze, eksternalizacija jeze, nadzor jeze, zaznana opora s strani vrstnikov, samozaznana priljubljenost, vizualno nasilje, besedilna viktimizacija in vizualna viktimizacija. Spremenljivke se povezujejo v pričakovani smeri in so večinoma nizke $(r<0,30)$, razen višjih korelacij med spremenljivkami SMVN (npr. vizualno nasilje in besedilno nasilje). 
Tabela 19: Opisne statistike in korelacije na vzorcu učencev SŠ

\begin{tabular}{|c|c|c|c|c|c|c|c|c|c|c|c|c|c|c|}
\hline & & M & SD & 1 & 2 & 3 & 4 & 5 & 6 & 7 & 8 & 9 & 10 & 11 \\
\hline 1 & $\mathrm{Spol}^{\mathrm{a}}$ & 0,65 & 1 & & & & & & & & & & & \\
\hline 2 & $\begin{array}{l}\text { Šolski } \\
\text { uspeh }\end{array}$ & 3,71 & 0,81 & $0,17^{* *}$ & & & & & & & & & & \\
\hline 3 & $\begin{array}{l}\text { Čas } \\
\text { uporabe }\end{array}$ & 203,04 & 125,08 & $0,17^{* *}$ & $-0,13$ & & & & & & & & & \\
\hline 4 & INT jeze & 3,81 & 1,07 & $0,20^{* *}$ & $0,11^{* *}$ & $0,11^{* *}$ & & & & & & & & \\
\hline 5 & EKS jeze & 2,83 & 0,98 & $-0,04$ & $-0,00$ & $0,09^{* *}$ & $0,20^{\prime \prime}$ & & & & & & & \\
\hline 6 & $\begin{array}{l}\text { Nadzor } \\
\text { jeze }\end{array}$ & 3,78 & 1,19 & $-0,15^{*}$ & 0,04 & $-0,13^{* *}$ & $-0,08^{* *}$ & $-0,43^{* *}$ & & & & & & \\
\hline 7 & Opora & 3,38 & 0,78 & $-0,10^{* *}$ & 0,04 & $-0,02$ & $-0,09$. & 0,01 & 0,05 & & & & & \\
\hline 8 & $\begin{array}{l}\text { Prilju- } \\
\text { bljenost }\end{array}$ & 2,94 & 0,85 & $-0,20^{* *}$ & $-0,02$ & $0,06^{*}$ & $-0,07^{*}$ & ,014* & $-0,02$ & $0,47^{* *}$ & & & & \\
\hline 9 & $\begin{array}{l}\text { VIZ } \\
\text { nasilje }\end{array}$ & 1,46 & 0,59 & $-0,13^{* *}$ & $-0,04$ & $0,15^{* *}$ & $0,10^{* *}$ & $0,21^{*}$ & $-0,08^{* *}$ & 0,04 & $0,23^{* *}$ & & & \\
\hline 10 & $\begin{array}{l}\text { BES } \\
\text { nasilje }\end{array}$ & 1,37 & 0,42 & $-0,14^{* *}$ & $-0,07$ & $0,12^{*}$ & $0,13^{* *}$ & $0,27^{* *}$ & $-0,08^{* \prime}$ & $-0,07$ & $0,16^{* *}$ & $0,61^{*}$ & & \\
\hline 11 & $\begin{array}{l}\text { Vizualna } \\
\text { VIK }\end{array}$ & 1,29 & 0,45 & $-0,12^{* *}$ & $-0,08^{* *}$ & $0,09^{* *}$ & $0,09^{* *}$ & $0,19^{* *}$ & $-0,06$ & $-0,11^{* *}$ & $0,08^{* *}$ & $0,49^{*}$ & $0,52^{* *}$ & \\
\hline 12 & $\begin{array}{l}\text { Besedilna } \\
\text { VIK }\end{array}$ & 1,31 & 0,45 & $-0,08^{*}$ & $-0,07^{*}$ & $0,11^{* *}$ & $0,12^{* *}$ & $0,19^{* *}$ & $-0,08^{* *}$ & $-0,16^{*}$ & 0,03 & $0,47^{* *}$ & $0,54^{* *}$ & $0,82^{* *}$ \\
\hline
\end{tabular}

Opombe. Spola: 0 = moški, I = ženski; ${ }^{*} \mathrm{p}<0,05 ;{ }^{* *} \mathrm{p}<0,0$ I; čas uporabe - čas aktivne uporabe socialnih omrežij; INT jeze - internalizacija jeze; EKS jeze - eksternalizacija jeze; opora - zaznana opora s strani vrstnikov; priljubljenost - samozaznana priljubljenost; VIZ nasilje - vizualno nasilje; BES nasilje - besedilno nasilje; vizualna VIK - vizualna viktimizacija; besedilna VIK - besedilna viktimizacija.

Tabela 20: Hierarhična regresijska analiza za spremenljivke, ki napovedujejo izvajanje vizualnega nasilja v srednji šoli

\begin{tabular}{|c|c|c|c|c|c|c|c|c|c|c|}
\hline \multicolumn{11}{|c|}{ Vizualno nasilje SŠ } \\
\hline & \multicolumn{2}{|c|}{ Model 1} & \multicolumn{2}{|c|}{ Model 2} & \multicolumn{2}{|c|}{ Model 3} & \multicolumn{2}{|c|}{ Model 4} & \multicolumn{2}{|c|}{ Model 5} \\
\hline & $\mathrm{B}$ & $\beta$ & $\mathrm{B}$ & $\beta$ & $\mathrm{B}$ & $\beta$ & $\mathrm{B}$ & $\beta$ & $\mathrm{B}$ & $\beta$ \\
\hline \multicolumn{11}{|c|}{ Korak 1: } \\
\hline Spol $^{\mathrm{a}}$ & $-0,21$ & $-0,17^{* *}$ & $-0,21$ & $-0,17^{* *}$ & $-0,17$ & $-0,13^{* *}$ & $-0,10$ & $-0,08^{* *}$ & $-0,05$ & $-0,04^{1}$ \\
\hline $\begin{array}{l}\text { Šolski } \\
\text { uspeh }\end{array}$ & 0,01 & 0,01 & 0,00 & 0,00 & $-0,01$ & $-0,01$ & 0,01 & 0,02 & 0,02 & 0,02 \\
\hline $\begin{array}{l}\text { Čas } \\
\text { uporabe }\end{array}$ & 0,00 & $0,18^{* *}$ & 0,00 & $0,15^{* *}$ & 0,00 & $0,13^{* *}$ & 0,00 & $0,10^{* *}$ & 0,00 & $0,07^{* *}$ \\
\hline $\mathrm{R}^{2}$ & & $0,05^{* *}$ & & & & & & & & \\
\hline
\end{tabular}




\begin{tabular}{|c|c|c|c|c|c|c|c|c|c|c|}
\hline \multicolumn{11}{|c|}{ Vizualno nasilje SŠ } \\
\hline & \multicolumn{2}{|c|}{ Model 1} & \multicolumn{2}{|c|}{ Model 2} & \multicolumn{2}{|c|}{ Model 3} & \multicolumn{2}{|c|}{ Model 4} & \multicolumn{2}{|c|}{ Model 5} \\
\hline & B & $\beta$ & B & $\beta$ & B & $\beta$ & B & $\beta$ & $\mathrm{B}$ & $\beta$ \\
\hline \multicolumn{11}{|c|}{ Korak 2: } \\
\hline INT jeze & & & 0,04 & $0,08^{*}$ & 0,05 & $0,09^{* *}$ & 0,03 & 0,05 & 0,01 & 0,02 \\
\hline EKS jeze & & & 0,10 & $0,17^{* *}$ & 0,09 & $0,14^{* *}$ & 0,04 & $0,07^{*}$ & 0,00 & 0,01 \\
\hline $\begin{array}{l}\text { Nadzor } \\
\text { jeze }\end{array}$ & & & $-0,01$ & $-0,01$ & $-0,01$ & $-0,01$ & $-0,01$ & $-0,02$ & $-0,01$ & $-0,03$ \\
\hline
\end{tabular}

$\Delta \mathrm{R}^{2} \quad 0,04^{* *}$

\begin{tabular}{|c|c|c|c|c|c|c|c|c|}
\hline \multicolumn{9}{|c|}{ Korak 3: } \\
\hline Opora & & & $-0,04$ & $-0,06$ & 0,02 & 0,03 & 0,04 & $0,06^{* 2}$ \\
\hline $\begin{array}{l}\text { Prilju- } \\
\text { bljenost }\end{array}$ & & & 0,14 & $0,21^{* *}$ & 0,11 & $0,16^{* *}$ & 0,07 & $0,10^{* *}$ \\
\hline$\Delta \mathrm{R}^{2}$ & & & & $0,03^{* *}$ & & & & \\
\hline \multicolumn{9}{|c|}{ Korak 4: } \\
\hline $\begin{array}{l}\text { Vizualna } \\
\text { VIK }\end{array}$ & & & & & 0,35 & $0,27^{* *}$ & 0,24 & $0,18^{* *}$ \\
\hline $\begin{array}{l}\text { Besedilna } \\
\text { VIK }\end{array}$ & & & & & 0,28 & $0,21^{* *}$ & 0,09 & $0,07^{1}$ \\
\hline$\Delta \mathrm{R}^{2}$ & & & & & & $0,19^{* *}$ & & \\
\hline \multicolumn{9}{|c|}{ Korak 5: } \\
\hline $\begin{array}{l}\text { Besedilno } \\
\text { nasilje }\end{array}$ & & & & & & & 0,63 & $0,45^{* *}$ \\
\hline$\Delta \mathrm{R}^{2}$ & & & & & & & & $0,13^{* *}$ \\
\hline $\mathrm{R}^{2}$ & $0,05^{* *}$ & $0,09^{* *}$ & & $0,12^{* *}$ & & $0,32^{* *}$ & & $0,44^{* *}$ \\
\hline $\mathrm{F} z a \Delta \mathrm{R}^{2}$ & $20,71^{* *}$ & $18,43^{* *}$ & & $22,27^{* *}$ & & $171,01^{* *}$ & & $274,58^{* *}$ \\
\hline
\end{tabular}

Opombe. Spola: o = moški, I = ženski; ${ }^{*} \mathrm{p}<0,0$; ${ }^{* *} \mathrm{p}<0,0$ I: Ip < 0,IO; 2 - supresorski učinek; čas uporabe - čas aktivne uporabe socialnih omrežij; INT jeze - internalizacija jeze; EKS jeze - eksternalizacija jeze; opora - zaznana opora s strani vrstnikov; priljubljenost - samozaznana priljubljenost, vizualna VIK - vizualna viktimizacija, besedilna VIK besedilna viktimizacija.

Iz Tabele 20 je razvidno, da demografske spremenljivke, vključene $\mathrm{v}$ prvem koraku, skupaj pojasnijo $5 \%$ variance vizualnega nasilja, pri čemer je čas aktivne uporabe socialnih omrežij značilen pozitiven napovednik, spol pa značilen negativen napovednik. $\mathrm{V}$ drugem koraku vnesene komponente jeze dodatno pojasnijo $4 \%$ variance, pri čemer sta internalizacija jeze in eksternalizacija jeze značilna pozitivna napovednika. Spremenljivke vezane na doživljanje odnosov v tretjem koraku dodatno pojasnijo 3 \% varian- 
ce, pri čemer je samozaznana priljubljenost značilen pozitiven napovednik. $\mathrm{V}$ četrtem koraku vneseni spremenljivki viktimizacije dodatno pojasnita še $19 \%$ variance, pri čemer sta vizualna viktimizacija in besedilna viktimizacija pozitivna značilna napovednika. Internalizacija jeze $\mathrm{v}$ tem koraku ni več značilen napovednik. Spremenljivka besedilno nasilje vnesena v petem koraku je značilen pozitiven napovednik, ki dodatno pojasni $13 \%$ variance. Spol in besedilna viktimizacija sta mejno značilna napovednika $(\alpha<0,10)$. $\mathrm{V}$ tem koraku postane zaznana opora statistično značilen pozitiven napovednik, čeprav je ob vnosu v regresijski model v tretjem koraku statistično neznačilen negativen napovednik, kar ponovno kaže na supresorski učinek (Smith et al., 1992). Skupaj napovedniki pojasnijo $44 \%$ variance vizualnega nasilja, pri čemer največja sprememba $\mathrm{v}$ deležu variance nastane $\mathrm{v}$ četrtem modelu. Spremenljivka besedilno nasilje je najmočnejši napovednik. Valence napovednikov kažejo, da so učenci z višjim časom aktivne uporabe socialnih omrežij, višjo samozaznano priljubljenostjo, višjo vizualno viktimizacijo in višjim besedilnim nasiljem, tisti, ki v višji meri poročajo o izvajanju vizualnega nasilja. Spol in besedilna viktimizacija sta mejno statistično značilna pri $\alpha<0,10$, kar nakazuje, da so fantje in učenci, ki doživljajo besedilno viktimizacijo, tisti, ki v višji meri izvajajo vizualno nasilje.

Tabela 2ı: Hierarhična regresijska analiza za spremenljivke, ki napovedujejo izvajanje besedilnega nasilja v srednji šoli

\begin{tabular}{|c|c|c|c|c|c|c|c|c|c|c|}
\hline \multicolumn{11}{|c|}{ Besedilno nasilje SŠ } \\
\hline & \multicolumn{2}{|c|}{ Model 1} & \multicolumn{2}{|c|}{ Model 2} & \multicolumn{2}{|c|}{ Model 3} & \multicolumn{2}{|c|}{ Model 4} & \multicolumn{2}{|c|}{ Model 5} \\
\hline & B & $\beta$ & B & $\beta$ & B & $\beta$ & B & $\beta$ & B & $\beta$ \\
\hline \multicolumn{11}{|c|}{ Korak 1: } \\
\hline Spol $^{a}$ & $-0,14$ & $-0,16^{* *}$ & $-0,14$ & $-0,16^{* *}$ & $-0,12$ & $-0,14^{* *}$ & $-0,07$ & $-0,08^{* *}$ & $-0,04$ & $-0,05^{*}$ \\
\hline $\begin{array}{l}\text { Šolski } \\
\text { uspeh }\end{array}$ & $-0,01$ & $-0,02$ & $-0,02$ & $-0,04$ & $-0,02$ & $-0,03$ & $-0,01$ & $-0,01$ & $-0,01$ & $-0,02$ \\
\hline $\begin{array}{l}\text { Čas } \\
\text { uporabe }\end{array}$ & 0,00 & $0,14^{* *}$ & 0,00 & $0,11^{* *}$ & 0,00 & $0,09^{* *}$ & 0,00 & $0,05^{*}$ & 0,00 & 0,01 \\
\hline $\mathrm{R}^{2}$ & & $0,04^{* *}$ & & & & & & & & \\
\hline \multicolumn{11}{|c|}{ Korak 2: } \\
\hline INT jeze & & & 0,04 & $0,10^{* *}$ & 0,04 & $0,10^{* *}$ & 0,02 & $0,06^{*}$ & 0,02 & $0,04^{1}$ \\
\hline EKS jeze & & & 0,10 & $0,24^{* *}$ & 0,10 & $0,22^{* *}$ & 0,06 & $0,15^{* *}$ & 0,05 & $0,12^{* *}$ \\
\hline $\begin{array}{l}\text { Nadzor } \\
\text { jeze }\end{array}$ & & & 0,01 & 0,02 & 0,01 & 0,03 & 0,01 & 0,03 & 0,01 & 0,03 \\
\hline$\Delta \mathrm{R}^{2}$ & & & & $0,07^{* *}$ & & & & & & \\
\hline
\end{tabular}




\begin{tabular}{|c|c|c|c|c|c|c|c|c|c|c|}
\hline \multicolumn{11}{|c|}{ Besedilno nasilje SŠ } \\
\hline & \multicolumn{2}{|c|}{ Model 1} & \multicolumn{2}{|c|}{ Model 2} & \multicolumn{2}{|c|}{ Model 3} & \multicolumn{2}{|c|}{ Model 4} & \multicolumn{2}{|c|}{ Model 5} \\
\hline & B & $\beta$ & B & $\beta$ & B & $\beta$ & $\mathrm{B}$ & $\beta$ & $\mathrm{B}$ & $\beta$ \\
\hline \multicolumn{11}{|c|}{ Korak 3: } \\
\hline Opora & & & & & $-0,09$ & $-0,16^{* *}$ & $-0,03$ & $-0,06^{*}$ & $-0,04$ & $-0,07^{* *}$ \\
\hline $\begin{array}{l}\text { Prilju- } \\
\text { bljenost }\end{array}$ & & & & & 0,09 & $0,18^{* *}$ & 0,07 & $0,13^{* *}$ & 0,03 & $0,07^{*}$ \\
\hline$\Delta \mathrm{R}^{2}$ & & & & & & $0,03^{* *}$ & & & & \\
\hline \multicolumn{11}{|c|}{ Korak 4: } \\
\hline $\begin{array}{l}\text { Vizualna } \\
\text { VIK }\end{array}$ & & & & & & & 0,18 & $0,20^{* *}$ & 0,08 & $0,08^{*}$ \\
\hline $\begin{array}{l}\text { Besedilna } \\
\text { VIK }\end{array}$ & & & & & & & 0,30 & $0,32^{* *}$ & 0,22 & $0,24^{* *}$ \\
\hline$\Delta \mathrm{R}^{2}$ & & & & & & & & $0,22^{* *}$ & & \\
\hline \multicolumn{11}{|c|}{ Korak 5: } \\
\hline $\begin{array}{l}\text { Vizualno } \\
\text { nasilje }\end{array}$ & & & & & & & & & 0,29 & $0,41^{* *}$ \\
\hline$\Delta \mathrm{R}^{2}$ & & & & & & & & & & $0,12^{* *}$ \\
\hline $\mathrm{R}^{2}$ & & $0,04^{* *}$ & & $0,11^{* *}$ & & $0,14^{* *}$ & & $0,37^{* *}$ & & $0,48^{* *}$ \\
\hline $\mathrm{F}$ za $\Delta \mathrm{R}^{2}$ & & $17,42^{* *}$ & & $33,58^{* *}$ & & $20,85^{* *}$ & & $213,77^{* *}$ & & $274,58^{* *}$ \\
\hline
\end{tabular}

Opombe. Spola: o = moški, I = ženski; ${ }^{*} \mathrm{p}<0,05 ;{ }^{* *} \mathrm{p}<0,0$ I: Ip $<0, \mathrm{IO}$; čas uporabe čas aktivne uporabe socialnih omrežij; INT jeze - internalizacija jeze; EKS jeze eksternalizacija jeze; opora - zaznana opora s strani vrstnikov; priljubljenost - samozaznana priljubljenost, vizualna VIK - vizualna viktimizacija, besedilna VIK - besedilna viktimizacija.

Iz Tabele 21 je razvidno, da demografske spremenljivke, vnesene v prvem koraku, skupaj pojasnijo $4 \%$ variance besedilnega nasilja, pri čemer je spol statistično značilen negativen napovednik in čas aktivne uporabe socialnih omrežij statistično značilen pozitiven napovednik. Komponente jeze vnesene v drugem koraku dodatno pojasnijo $7 \%$ variance. Internalizacija jeze in eksternalizacija jeze sta statistično značilna pozitivna napovednika. V tretjem koraku vneseni spremenljivki vrstniških odnosov dodatno pojasnita $3 \%$ variance, pri čemer je zaznana opora statistično značilen negativen napovednik in samozaznana priljubljenost statistično značilen pozitiven napovednik. V četrtem koraku vneseni spremenljivki viktimizacije, besedilna viktimizacija in vizualna viktimizacija, dodatno pojasnita $22 \%$ variance in sta statistično značilna pozitivna napovednika. V petem koraku vnesena spremenljivka vizualno nasilje dodatno pojasni $12 \%$ variance in je statistično značilen pozitiven napovednik. Internalizacija jeze $\mathrm{v}$ tem koraku postane mejno statistično značilna, medtem ko čas aktivne 
uporabe socialnih omrežij $\mathrm{v}$ tem koraku izgubi statistično značilnost. Skupaj napovedniki pojasnijo $48 \%$ variance besedilnega nasilja, pri čemer je najmočnejši napovednik vizualno nasilje. Valence napovednikov kažejo, da so učenci z višjo eksternalizacijo jeze, nižjo zaznano oporo s strani vrstnikov, višjo samozaznano priljubljenostjo, višjo besedilno viktimizacijo, višjo vizualno viktimizacijo in višjim vizualnim nasiljem tisti, ki v višji meri poročajo o izvajanju besedilnega nasilja. Valenca napovednikov prav tako kaže, da fantje v primerjavi z dekleti poročajo o več izvajanju besedilnega nasilja. Spremenljivka internalizacija jeze, ki je mejno statistično značilna pri $\alpha<0,10$, nakazuje, da višje ravni internalizacije jeze napovedujejo več besedilnega nasilja.

\section{Diskusija}

Namen pričujočega prispevka je bil preveriti, kako posamezne značilnosti učencev napovedujejo izvajanje vizualnega in besedilnega spletnega medvrstniškega nasilja (SMVN) pri osnovnošolcih in srednješolcih. Preučila sva napovedno vrednost demografskih spremenljivk (spol, šolski uspeh, čas aktivne uporabe socialnih omrežij), komponent jeze (internalizacija jeze, eksternalizacija jeze, nadzor jeze), doživljanja vrstniških odnosov (samozaznana priljubljenost, zaznana opora s strani vrstnikov) in izkušenj s spletno viktimizacijo (vizualna viktimizacija, besedilna viktimizacija) ter izvajanjem spletnega nasilja (vizualno nasilje, besedilno nasilje). Rezultati kažejo, da so si napovedniki obeh oblik SMVN precej podobni.

Kot najmočnejši pozitiven napovednik ene oblike nasilja se je pokazala druga oblika nasilja. Torej, da vizualno nasilje najmočneje napoveduje besedilno nasilje in da besedilno nasilje najmočneje napoveduje vizualno nasilje. To pomeni, da učenec, ki izvaja več vizualnega nasilja, prav tako izvaja več besedilnega nasilja in obratno. Ta ugotovitev se je potrdila v vseh regresijskih modelih na OŠ in SŠ vzorcu ter je v skladu z raziskavami (Kowalski et al., 2014; Guo, 2016), ki ugotavljajo, da so najmočnejši napovedniki izvajanja SMVN vezani na izvajanje druge oblike nasilja, kar pomeni, da rezultati nakazujejo na medsebojno prepletenost različnih oblik spletnega nasilnega vedenja.

$\mathrm{K}$ regresijskim modelom sta značilno prispevali tudi spremenljivki viktimizacije, vizualna viktimizacija in besedilna viktimizacija. Vizualna viktimizacija pozitivno napoveduje vizualno nasilje v OŠ in SŠ ter vizualno nasilje v SŠ, medtem ko besedilna viktimizacija pozitivno napoveduje besedilno nasilje $\mathrm{v}$ OŠ in SŠ ter negativno napoveduje vizualno nasilje v OŠ. 
Ti rezultati kažejo, da je pomemben dejavnik tveganja za izvajanje vizualnega in/ali besedilnega nasilja doživljanje viktimizacije, kar je v skladu z metaanalizo dejavnikov SMVN (Kowalski et al., 2014). Nasprotno se je pokazalo zgolj pri besedilni viktimizaciji kot napovedniku vizualnega nasilja v OŠ, kjer višje doživljanje besedilne viktimizacije pomeni manj pogostejše vizualno nasilje. Glede na pozitiven koeficient korelacije med vizualnim nasiljem in besedilno viktimizacijo $\mathrm{v}$ OŠ, je smiselno predpostavljati, da gre negativno valenco napovednika pripisati supresorskemu učinku (angl. »supressor effect«) (Smith et al., 1992). Omenjeni rezultati nakazujejo, da so spletni nasilneži tudi sami žrtve nasilja, kar lahko v kontekstu SMVN pomeni dvoje: spletni nasilneži bodisi izvajajo nasilje kot odgovor na lastno viktimizacijo ali pa je spletno nasilje povod, da nasilneži postanejo žrtve nasilja s strani drugih učencev.

Demografske spremenljivke (spol, šolski uspeh, čas aktivne uporabe socialnih omrežij) pojasnjujejo večji delež variance vizualnega nasilja in besedilnega nasilja v OŠ v primerjavi s SŠ. Čas aktivne uporabe socialnih omrežij se je pokazal kot pozitiven in statistično značilen napovednik v vseh regresijskih modelih, razen pri napovedovanju besedilnega nasilja v SŠ, kjer ob vključitvi drugih napovednikov izgubi statistično značilnost. Pričujoči rezultati so v skladu z raziskavami (Guo, 2016; Kowalski et al., 2019; Lee in Shin, 2017), ki ugotavljajo, da učenci, ki več časa uporabljajo splet, poročajo o pogostejšem izvajanju SMVN. Omenjeni rezultati nakazujejo na rizično uporabo interneta, saj imajo učenci, ki veliko uporabljajo socialna omrežja več možnosti, da izvajajo nasilje.

Spol se je izkazal kot statistično značilen negativen napovednik besedilnega nasilja v SŠ in mejno statistično značilen negativen napovednik $v i$ zualnega nasilja v SŠ ter besedilnega nasilja v OŠ. Rezultati nakazujejo, da so fantje $\mathrm{v}$ primerjavi $\mathrm{z}$ dekleti poročali o pogostejšem izvajanju obeh preučevanih oblik nasilja, kar je v skladu z nekaterimi raziskavami (Aboujaoude et al., 2015; Baldry et al., 2016; Lapidot-Lefler in Dolev-Cohen, 2015). V končnih regresijskih modelih je spol relativno šibek napovednik, vendar močnejši napovednik na SŠ vzorcu v primerjavi z OŠ vzorcem, kar nakazuje, da bi lahko bile razlike med spoloma v izvajanju nasilja bolj izrazite v SŠ.

Šolski uspeh se v nobenem izmed modelov ni izkazal kot statistično značilen napovednik, kar ni $\mathrm{v}$ skladu $\mathrm{z}$ dosedanjimi ugotovitvami (npr. Kowalski et al., 2014), ki poročajo, da se nižji šolski uspeh povezuje z izvajanjem SMVN. Na omenjene rezultate je morda vplivala uporabljena mera šolskega uspeha, ki je vključevala zgolj povprečje ocen treh predmetov (slo- 
venščine, matematike, prvega tujega jezika) in ne učnega uspeha iz učenčevega spričevala ali redovalnice.

Komponente jeze (internalizacija jeze, eksternalizacija jeze, nad$z o r$ jeze) $\mathrm{v}$ vseh regresijskih modelih pomembno prispevajo k pojasnjevanju variance vizualnega nasilja in besedilnega nasilja. Eksternalizacija jeze je pozitiven napovednik besedilnega nasilja v OŠ in SŠ, kar kaže, da višja eksternalizacija jeze napoveduje pogostejše izvajanje besedilnega nasilja. Podobno se kaže tudi pri napovedovanju vizualnega nasilja v OŠ in SŠ, vendar ob vnosu spremenljivk doživljanja odnosov, viktimizacije in nasilja na naslednjih korakih, eksternalizacija jeze izgubi statistično značilnost. Internalizacija jeze je mejno značilen pozitiven napovednik besedilnega nasilja v SŠ, kar nakazuje, da višja internalizacija jeze pomeni več izvajanja besedilnega nasilja. Nadzor jeze se je pokazal kot negativni napovednik izvajanja vizualnega nasilja v osnovni šoli, kar pomeni, da je izvajanje vizualnega nasilja $\mathrm{v}$ osnovni šoli lahko povezano s pomanjkljivim nadzorom jeze, ki se jo učenci učijo obvladovati. Omenjeni rezultati komponent jeze kot napovednikov so $\mathrm{v}$ skladu $\mathrm{z}$ raziskavami, ki ugotavljajo, da je izvajanje SMVN povezano $\mathrm{z}$ doživljanjem jeze (Aricak in Ozbay, 2016; Kowalski et al., 2014; Wang et al., 2017) in da komponente jeze podobno napovedujejo tradicionalne oblike nasilnega vedenja (telesno, besedno, odnosno) (Košir et al., 2020). Komponente jeze večinoma izgubijo statistično značilnost ob vnosu nekaterih drugih spremenljivk (predvsem nasilja in viktimizacije), kar pomeni, da je varianca, ki bi jo v napovedovanju izvajanja SMVN pojasnile komponente izražanja jeze, že zajeta v spremenljivkah SMVN. Obenem pa lahko to nakazuje na delno prekrivanje konceptov izražanja jeze in izvajanja ter doživljanja SMVN.

Samozaznana priljubljenost in zaznana opora s strani vrstnikov sta bili uporabljeni kot meri doživljanja vrstniških odnosov. Samozaznana priljubljenost se je izkazala kot pozitiven napovednik vizualnega nasilja v OŠ in SŠ ter besedilnega nasilja v SŠ. Torej, učenci, ki se zaznavajo kot bolj priljubljene, poročajo o višjih ravneh izvajanja vizualnega in besedilnega nasilja. Omenjena ugotovitev je v skladu z literaturo (Bayraktar in Wright, 2021), kar nakazuje, da samozaznana priljubljenost v razredu učence lahko opogumlja za izvajanje nasilja. Zaznana opora s strani vrstnikov negativno napoveduje besedilno nasilje v SŠ, kar pomeni, da nižja zaznana opora napoveduje več izvajanja besedilnega nasilja, kar je v skladu z dosedanjimi ugotovitvami (Calvete et al., 2010; Williams in Guerra, 2007). Ker je zaznana opora bila napovednik samo v eden izmed regresijskih modelov, je mo- 
goče sklepati, da zaznana opora vrstnikov v manjši meri prispeva k izvajanju SMVN.

\section{Zaključek}

Raziskava doprinaša k podrobnejšemu razumevanju nekaterih dejavnikov izvajanja spletnega medvrstniškega nasilja med osnovnošolci in srednješolci v slovenskem šolskem prostoru. Razumevanje dejavnikov, ki so povezani z izvajanjem SMVN, lahko pripomore k prepoznavanju učencev, ki imajo višjo stopnjo tveganja za to, da postanejo izvajalci SMVN. Predvsem je to pomembno pri obravnavanih oblikah spletnega nasilja, ki se še težje odkrijejo v primerjavi s tradicionalnim (telesnim, besednim, odnosnim). Dodatno raziskava prispeva k bolj celovitejšem razumevanju SMVN, saj se osredinja na dve distinktivni obliki nasilja: vizualno nasilje in besedilno nasilje.

Kljub temu je treba rezultate prispevka povzemati previdno, saj ima raziskava nekaj pomanjkljivosti. Prvič, podatki bili zbrani priložnostno, kar onemogoča posploševanje rezultatov na populacijo učencev višjih razredov osnovnih šol in dijakov srednjih šol. Drugič, uporabljene so bile zgolj mere samoporočanja, kar lahko privede do podcenitve ali precenitve dejanske pogostosti SMVN. Prav tako pa so se nekatere mere izkazale kot problematične iz vidika zanesljivosti, zato bi bilo smiselno podatke triangulirati $\mathrm{z}$ uporabo različnih metod zbiranja podatkov (npr. zaznavanje spletnega nasilja s strani učiteljev, vrstniške nominacije). Tretjič, vključeni so bili le dejavniki na ravni posameznika, čeprav aktualne raziskave medvrstniškega nasilja vse bolj vključujejo dejavnike na ravni razreda in šole (Låftman et al., 2017).

Aplikativna vrednost raziskave se nanaša na poznavanje dejavnikov povezanih z različnimi oblikami nasilja, kar je lahko $\mathrm{v}$ pomoč učiteljem in šolskim svetovalnim delavcem pri preprečevanju ter prepoznavanju spletnega medvrstniškega nasilja med učenci. Poznavanje dejavnikov povezanih z izvajanjem SMVN in značilnosti SMVN nasploh, se lahko prenese $\mathrm{v}$ intervencije ali dobre prakse na šoli: 1) ozaveščanje učencev o omejevanju uporabe spleta, saj več časa kot ga učenci preživijo na spletu več priložnosti imajo za udejstvovanje v nasilnem vedenju; 2) v največji možni meri na šoli skušati delovati preventivno še preden se pojavljajo ali ponavljajo primeri SMVN, saj so najmočnejši napovedniki povezani prav z izvajanjem in doživljanjem nasilja, kar pomeni, da mora biti izhodiščna točka preventiva nasilja, še preden se le to zgodi in 3) priljubljene učence se lahko opolnomoči z bolj konstruktivnimi načini za ohranjanje priljubljenosti in statu- 
sa v razredu, ki ne temeljijo na nasilju (npr. spodbujanje sodelovanja med učenci). V nadaljnje raziskave dejavnikov, ki napovedujejo vizualno in besedilno nasilje je smiselno vključiti tudi druge koncepte (npr. osamljenost, odnosi med učenci in učitelji, samopodobo) in preveriti, če se učenci, ki izvajajo vizualno in besedilno nasilje razlikujejo med seboj (npr. $\mathrm{z}$ analizo latentnih profilov).

\section{Literatura}

Aboujaoude, Elias, Matthew W. Savage, Vladan Starcevic in Wael O. Salame. 2015. 'Cyberbullying: Review of an Old Problem Gone Viral'. Journal of Adolescent Health 57: 10-18. https://doi.org/10.1016/j.jadohealth.2015.04.011.

Antoniadou, Nafsika, Constantinos M. Kokkinos in Angelos Markos. 2016. 'Possible Common Correlates between Bullying and Cyber-Bullying among Adolescents'. Psicología Educativa 22 (1): 27-38. https://doi. org/10.1016/j.pse.2016.01.003.

Aricak, Osman Tolga in Ahmet Ozbay. 2016. 'Investigation of the Relationship between Cyberbullying, Cybervictimization, Alexithymia and Anger Expression Styles among Adolescents'. Computers in Human Behavior 55 (February): 278-85. https://doi.org/10.1016/j.chb.2015.09.015.

Baldry, Anna C, David P. Farrington in Anna Sorrentino. 2015. “Am I at Risk of Cyberbullying"? A Narrative Review and Conceptual Framework for Research on Risk of Cyberbullying and Cybervictimization: The Risk and Needs Assessment Approach'. Aggression and Violent Behavior 23 (July): 36-51. https://doi.org/10.1016/j.avb.2015.05.014.

Baldry, Anna C., David P. Farrington in Anna Sorrentino. 2016. 'Cyberbullying in Youth: A Pattern of Disruptive Behaviour'. Psicología Educativa 22 (1): 19-26. https://doi.org/10.1016/j.pse.2016.02.001.

Bayraktar, Fatih in Michelle F Wright. 2021. 'The Longitudinal Associations of Cyberbullying and Cybervictimization: Preliminary Findings from a Two-Wave Study'. In Child and Adolescent Online Risk Exposure: An Ecological Perspective, edited by Michelle F Wright and Lawrence B Schiamberg, 129-43. Academic Press: An imprint of Elsevier. https://doi. org/10.1016/B978-0-12-817499-9.00007-7.

Brečko, Barbara Neža. 2019. 'Spletno nadlegovanje v šolah z vidika spola'. Šolsko polje 30 (3-4): 113-30. https://doi.org/10.32320/1581-6044.30(3-4)113130 . 
Brochado, Sandra, Sara Soares in Sílvia Fraga. 2017. 'A Scoping Review on Studies of Cyberbullying Prevalence Among Adolescents'. Trauma, Violence, \& Abuse 18 (5): 523-31. https://doi.org/10.1177/1524838016641668.

Bruyn, Eddy H. de, Antonius H. N. Cillessen in Inge B. Wissink. 2010. 'Associations of Peer Acceptance and Perceived Popularity With Bullying and Victimization in Early Adolescence'. The Journal of Early Adolescence 30 (4): 543-66. https://doi.org/10.1177/0272431609340517.

Calvete, Esther, Izaskun Orue, Ana Estévez, Lourdes Villardón in Patricia Padilla. 2010. 'Cyberbullying in Adolescents: Modalities and Aggressors' Profile'. Computers in Human Behavior 26 (5): 1128-35. https://doi. org/10.1016/j.chb.2010.03.017.

Campbell, Marilyn A., Phillip T. Slee, Barbara Spears, Des Butler in Sally Kift. 2013. 'Do Cyberbullies Suffer Too? Cyberbullies' Perceptions of the Harm They Cause to Others and to Their Own Mental Health'. School Psychology International 34 (6): 613-29. https://doi.org/10.1177/0143034313479698.

Cassidy, Wanda, Chantal Faucher in Margaret Jackson. 2013. 'Cyberbullying among Youth: A Comprehensive Review of Current International Research and Its Implications and Application to Policy and Practice'. School Psychology International 34 (6): 575-612. https://doi. org/10.1177/0143034313479697.

Chen, Liang, Shirley S. Ho in May O. Lwin. 2017. 'A Meta-Analysis of Factors Predicting Cyberbullying Perpetration and Victimization: From the Social Cognitive and Media Effects Approach'. New Media \& Society 19 (8): 1194-1213. https://doi.org/10.1177/1461444816634037.

Cillessen, Antonius H N in Peter E L Marks. 2011. 'Conceptualizing and Measuring Popularity'. In Popularity in the Peer System, edited by Antonius H N Cillessen, David Schwartz, and Lara Mayeux, 25-56. Guilford Press.

Del Rey, Rosario, Lambros Lazuras, José A. Casas, Vassilis Barkoukis, Rosario Ortega-Ruiz in Haralambos Tsorbatzoudis. 2016. 'Does Empathy Predict (Cyber) Bullying Perpetration, and How Do Age, Gender and Nationality Affect This Relationship?' Learning and Individual Differences 45 (January): 275-81. https://doi.org/10.1016/j.lindif.2015.11.021.

Dredge, Rebecca, John Gleeson in Xochitl de la Piedad Garcia. 2014. 'Presentation on Facebook and Risk of Cyberbullying Victimisation'. Computers in Human Behavior 40 (November): 16-22. https://doi.org/10.1016/j. chb.2014.07.035.

Erdur-Baker, Özgür. 2010. 'Cyberbullying and Its Correlation to Traditional Bullying, Gender and Frequent and Risky Usage of Internet-Mediated 
Communication Tools'. New Media \& Society 12 (1): 109-25. https://doi. org/10.1177/146144480934126o.

Gámez-Guadix, Manuel, Izaskun Orue, Peter K. Smith in Esther Calvete. 2013. 'Longitudinal and Reciprocal Relations of Cyberbullying With Depression, Substance Use, and Problematic Internet Use Among Adolescents'. Journal of Adolescent Health 53 (4): 446-52. https://doi.org/10.1016/j.jadohealth.2013.03.030.

Griezel, Lucy, Linda R. Finger, Gawaian H. Bodkin-Andrews, Rhonda G. Craven in Alexander Seeshing Yeung. 2012. 'Uncovering the Structure of and Gender and Developmental Differences in Cyber Bullying'. The Journal of Educational Research 105 (6): 442-55. https://doi.org/10.1080/0022067 1.2011.629692.

Guo, Siying. 2016. 'A Meta-Analysis of the Predictors of Cyberbullying Perpetration and Victimization'. Psychology in the Schools 53 (4): 432-53. https:// doi.org/10.1002/pits.21914.

Hemphill, Sheryl A., Aneta Kotevski, Michelle Tollit, Rachel Smith, Todd I. Herrenkohl, John W. Toumbourou in Richard F. Catalano. 2012. 'Longitudinal Predictors of Cyber and Traditional Bullying Perpetration in Australian Secondary School Students'. Journal of Adolescent Health 51 (1): 59-65. https://doi.org/10.1016/j.jadohealth.2011.11.019.

Hinduja, Sameer in Justin W. Patchin. 2010. 'Bullying, Cyberbullying, and Suicide'. Archives of Suicide Research 14 (3): 206-21. https://doi.org/10.1080/1 3811118.2010 .494133 .

Javornik, Špela, Plamen Mirazchiyski in Nada Trunk Širca. 2019. 'Bullying of Eighth Graders in Slovenian Primary Schools (Secondary Analysis of ICCS 2016)'. Šolsko Polje 30 (5-6): 79-97. https://doi.org/10.32320/15816044.30(5-6)79-97.

Johnson, David W., Roger Johnson in Douglas Anderson. 1983. 'Social Interdependence and Classroom Climate’. The Journal of Psychology 114 (1): 13542. https://doi.org/10.1080/00223980.1983.9915406.

Kaiser, Sabine, Henriette Kyrrestad in Sturla Fossum. 2020. 'Cyberbullying Status and Mental Health in Norwegian Adolescents'. Scandinavian Journal of Psychology 61 (5): 707-13. https://doi.org/10.1111/sjop.12656.

Košir, Katja. 2013. Socialni odnosi v šoli. Maribor: Subkulturni azil.

Košir, Katja, Lucia Klasinc, Tanja Špes, Tina Pivec, Gašper Cankar in Marina Horvat. 2020. 'Predictors of Self-Reported and Peer-Reported Victimization and Bullying Behavior in Early Adolescents: The Role of Scho- 
ol, Classroom, and Individual Factors'. European Journal of Psychology of Education 35 (2): 381-402. https://doi.org/10.1007/s10212-019-00430-y.

Košir, Katja in Sonja Pečjak. 2007. 'Dejavniki, ki se povezujejo s socialno sprejetostjo v različnih obdobjih šolanja’. Psihološka obzorja 16 (3): 49-73.

Košir, Katja, Tina Pivec, Lucia Klasinc, Tanja Špes in Marina Horvat. 2018. 'Psihosocialne značilnosti učencev kot napovedniki različnih oblik medvrstniške viktimizacije in nasilnega vedenja'. Psihološka obzorja / Horizons of Psychology, December, 171-86. https://doi.org/10.20419/2018.27.494.

Kowalski, Robin M., Gary W. Giumetti, Amber N. Schroeder in Micah R. Lattanner. 2014. 'Bullying in the Digital Age: A Critical Review and Meta-Analysis of Cyberbullying Research among Youth.' Psychological Bulletin 140 (4): 1073-1137. https://doi.org/10.1037/aoo35618.

Kowalski, Robin M. in Susan P. Limber. 2007. 'Electronic Bullying Among Middle School Students'. Journal of Adolescent Health 41 (6): S22-30. https://doi.org/10.1016/j.jadohealth.2007.08.017.

Kowalski, Robin M. in Susan P. Limber. 2013. 'Psychological, Physical, and Academic Correlates of Cyberbullying and Traditional Bullying'. Journal of Adolescent Health 53 (1): S13-20. https://doi.org/10.1016/j.jadohealth.2012.09.018.

Kowalski, Robin M., Susan P. Limber in Annie McCord. 2019. 'A Developmental Approach to Cyberbullying: Prevalence and Protective Factors'. Aggression and Violent Behavior 45 (March): 20-32. https://doi. org/10.1016/j.avb.2018.02.009.

Låftman, Sara B, Viveca Östberg in Bitte Modin. 2017. 'School Leadership and Cyberbullying-A Multilevel Analysis'. Int. J. Environ. Res. Public Health, 10.

Langos, Colette. 2012. 'Cyberbullying: The Challenge to Define'. Cyberpsychology, Behavior, and Social Networking 15 (6):285-89. https://doi.org/10.1089/ cyber.2011.0588.

Lapidot-Lefler, Noam in Michal Dolev-Cohen. 2015. 'Comparing Cyberbullying and School Bullying among School Students: Prevalence, Gender, and Grade Level Differences'. Social Psychology of Education 18 (1): 1-16. https://doi.org/10.1007/s11218-014-9280-8.

Lee, Changho in Namin Shin. 2017. 'Prevalence of Cyberbullying and Predictors of Cyberbullying Perpetration among Korean Adolescents'. Computers in Human Behavior 68 (March): 352-58. https://doi.org/10.1016/j. chb.2016.11.047. 
Li, Qing. 2006. 'Cyberbullying in Schools: A Research of Gender Differences'. School Psychology International 27 (2): 157-70. https://doi. org/10.1177/0143034306064547.

Olweus, Dan. 1994. 'Bullying at School: Basic Facts and Effects of a School Based Intervention Program'. Journal of Child Psychology and Psychiatry 35 (7): 1171-90. https://doi.org/10.1111/j.1469-7610.1994.tbo1229.x.

Parada, Roberto H. 2006. 'School Bullying: Psychosocial Determinants and Effective Intervention.' Doctoral Disseration. University of Western Sydney, Penrith, New South Wales, Australia.

Patchin, Justin W. in Sameer. Hinduja. 2006. 'Bullies Move Beyond the Schoolyard: A Preliminary Look at Cyberbullying'. Youth Violence and Juvenile Justice 4 (2): 148-69. https://doi.org/10.1177/1541204006286288.

Patchin, Justin W. in Sameer Hinduja. 2010. 'Cyberbullying and Self-Esteem*'. Journal of School Health 8o (12): 614-21. https://doi.org/10.1111/j.17461561.2010.00548.x.

Patchin, Justin W. in Sameer Hinduja. 2011. 'Traditional and Nontraditional Bullying Among Youth: A Test of General Strain Theory'. Youth \& Society 43 (2): 727-51. https://doi.org/10.1177/0044118X10366951.

Pečjak, Sonja in Tina Pirc. 2017. 'School Climate in Peer Bullying: Observers' and Active Participants' Perceptions'. Psihološka Obzorja / Horizons of Psychology 26 (September): 74-82. https://doi.org/10.20419/2017.26.470.

Skilbred-Fjeld, Sara, Silje Endresen Reme in Svein Mossige. 2020. 'Cyberbullying Involvement and Mental Health Problems among Late Adolescents'. Cyberpsychology: Journal of Psychosocial Research on Cyberspace 14 (1). https://doi.org/10.5817/CP2020-1-5.

Smith, Peter K., Jess Mahdavi, Manuel Carvalho, Sonja Fisher, Shanette Russell in Neil Tippett. 2008. 'Cyberbullying: Its Nature and Impact in Secondary School Pupils'. Journal of Child Psychology and Psychiatry 49 (4): 37685. https://doi.org/10.1111/j.1469-7610.2007.01846.x.

Smith, Richard L, Joel W Ager jr. in David L Williams. 1992. 'Supressor Variables in Multiple Regression/Correlation'. Educational and Psychological Measurement 52: 17-29. https://doi.org/10.1177/001316449205200102.

Sourander, Andre, Anat Brunstein Klomek, Maria Ikonen, Jarna Lindroos, Terhi Luntamo, Merja Koskelainen, Terja Ristkari in Hans Helenius. 2010. 'Psychosocial Risk Factors Associated With Cyberbullying Among Adolescents: A Population-Based Study'. Archives of General Psychiatry 67 (7): 720-28. https://doi.org/10.1001/archgenpsychiatry.2010.79. 
Sticca, Fabio, Sabrina Ruggieri, Françoise Alsaker in Sonja Perren. 2013. 'Longitudinal Risk Factors for Cyberbullying in Adolescence: Longitudinal Risk Factors for Cyberbullying’. Journal of Community \& Applied Social Psychology 23 (1): 52-67. https://doi.org/10.1002/casp.2136.

Šulc, Ajda in Aleš Bučar Ručman. 2019. 'Šola in medvrstniško nasilje v Sloveniji: raziskovalni pristopi, metode in metaanaliza dosedanjega raziskovanja v Sloveniji'. Šolsko polje XXX (1-2): 63-88. https://doi.org/10.32320/15816044.30(1-2)63-88.

Wang, Xingchao, Li Yang, Jiping Yang, Pengcheng Wang in Li Lei. 2017. 'Trait Anger and Cyberbullying among Young Adults: A Moderated Mediation Model of Moral Disengagement and Moral Identity'. Computers in Human Behavior 73 (August): 519-26. https://doi.org/10.1016/j.chb.2017.03.073.

Williams, Kirk R. in Nancy G. Guerra. 2007. 'Prevalence and Predictors of Internet Bullying'. Journal of Adolescent Health 41 (6): S14-21. https://doi. org/10.1016/j.jadohealth.2007.08.018.

Wright, Michelle F. 2014. 'Longitudinal Investigation of the Associations Between Adolescents' Popularity and Cyber Social Behaviors'. Journal of School Violence 13 (3): 291-314. https://doi.org/10.1080/15388220.2013.8492 o1.

Zych, Izabela, David P. Farrington in Maria M. Ttofi. 2019. 'Protective Factors against Bullying and Cyberbullying: A Systematic Review of Meta-Analyses'. Aggression and Violent Behavior 45 (March): 4-19. https://doi. org/10.1016/j.avb.2018.06.008. 